\title{
Characterizing the distribution and rates of microbial sulfate reduction at Middle Valley hydrothermal vents
}

\author{
Kiana L Frank, Daniel R Rogers, Heather C Olins, Charles Vidoudez and Peter R Girguis \\ Department of Organismic and Evolutionary Biology, Harvard University, Cambridge, MA, USA
}

\begin{abstract}
Few studies have directly measured sulfate reduction at hydrothermal vents, and relatively little is known about how environmental or ecological factors influence rates of sulfate reduction in vent environments. A better understanding of microbially mediated sulfate reduction in hydrothermal vent ecosystems may be achieved by integrating ecological and geochemical data with metabolic rate measurements. Here we present rates of microbially mediated sulfate reduction from three distinct hydrothermal vents in the Middle Valley vent field along the Juan de Fuca Ridge, as well as assessments of bacterial and archaeal diversity, estimates of total biomass and the abundance of functional genes related to sulfate reduction, and in situ geochemistry. Maximum rates of sulfate reduction occurred at $90{ }^{\circ} \mathrm{C}$ in all three deposits. Pyrosequencing and functional gene abundance data revealed differences in both biomass and community composition among sites, including differences in the abundance of known sulfate-reducing bacteria. The abundance of sequences for Thermodesulfovibro-like organisms and higher sulfate reduction rates at elevated temperatures suggests that Thermodesulfovibro-like organisms may have a role in sulfate reduction in warmer environments. The rates of sulfate reduction presented here suggest that-within anaerobic niches of hydrothermal deposits-heterotrophic sulfate reduction may be quite common and might contribute substantially to secondary productivity, underscoring the potential role of this process in both sulfur and carbon cycling at vents.
\end{abstract}

The ISME Journal (2013) 7, 1391-1401; doi:10.1038/ismej.2013.17; published online 28 March 2013

Subject Category: Geomicrobiology and microbial contributions to geochemical cycles

Keywords: hydrothermal vent; microbial ecology; primary productivity; sulfate reduction

\section{Introduction}

Deep-sea hydrothermal vent ecosystems are complex dynamic habitats characterized by steep gradients in temperature and geochemistry (Jannasch and Mottl, 1985). In these habitats, as hot hydrothermal fluid mixes with cold seawater, the precipitation of minerals creates large and complex hydrothermal chimney deposits. Within these permeable mineral structures, the continued mixing of chemically reduced, vent-derived fluids and oxidized seawater provides favorable conditions that support the growth of endolithic microbial communities (Schrenk et al., 2003).

Sulfide oxidation is considered to be one of the most important microbial chemosynthetic pathways at ridge ecosystems, as evidenced by the ubiquity of sulfide-oxidizing Epsilon- and Gammaproteobacteria at ridge environments (Nakagawa et al.,

Correspondence: PR Girguis, Department of Organismic and Evolutionary Biology, Harvard University, 16 Divinity Avenue, Cambridge, MA 02138-2020, USA.

E-mail: pgirguis@oeb.harvard.edu

Received 1 August 2012; revised 10 January 2013; accepted 15 January 2013; published online 28 March 2013
2004, 2005; Campbell et al., 2006; Huber et al., 2007; Nakagawa and Takai, 2008). To date, significantly less attention has been paid to the distribution and magnitude of sulfate reduction at vents, though sulfate-reducing bacteria and archaea have frequently been isolated from deep-sea hydrothermal environments (Jannasch et al., 1988; Blöchl et al., 1997; Alazard et al., 2003; Audiffrin et al., 2003; Houghton et al., 2007). Moreover, analyses of functional genes that express key proteins required for sulfate reduction suggest there is a high diversity of sulfate-reducing organisms at vents, higher than predicted via $16 \mathrm{~S}$ ribosomal RNA (rRNA) gene analyses alone (Nakagawa et al., 2004; Nercessian et al., 2005).

From a biogeochemical and bioenergetic perspective, both sulfide oxidation and sulfate reduction would be favored at hydrothermal vents, although to varying degrees as a function of environmental chemistry. Sulfide oxidation is most favorable when coupled to oxygen or nitrate as an electron acceptor (Amend and Shock, 2001). Around vents, sulfide is typically in micromolar to millimolar concentrations (Butterfield et al., 1994a, b), while oxygen and nitrate are around 110 and $40 \mu \mathrm{M}$, respectively (Johnson et al., 1986). In contrast, sulfate reduction 
is highly favored in anoxic niches at vents, as it is in other marine anaerobic environments (Muyzer and Stams, 2008). Here, as in most marine systems, sulfate is abundant at $28 \mathrm{~mm}$ (Dittmar, 1884), two to three orders of magnitude higher than oxygen. At vents, sulfate reduction would occur in regimes where seawater-derived sulfate is still present but oxygen is absent as, for example, within hydrothermal vent deposits. Sulfate-reducing microorganisms commonly use hydrogen and/or dissolved organic matter as electron donors, both of which are found within hydrothermal fluids (Cruse and Seewald, 2006; Lang et al., 2006). Sulfate reduction-as a function of its extent and magnitude-could readily influence the cycling of sulfur and sulfur isotopes, as well as carbon, within hydrothermal environments.

To date, studies have quantified rates of sulfate reduction in hydrothermal-influenced sediments (Jorgensen et al., 1992; Elsgaard et al., 1994a,b, 1995; Weber and Jorgensen, 2002; Kallmeyer and Boetius, 2004) and isolated vent micro-organisms (Hoek et al., 2003). In contrast to the numerous studies of sulfate reduction in marine sediments (Canfield, 1989), studies of sulfate reduction in hydrothermal deposits are few (Bonch-Osmolovskaya et al., 2011), due in part to the challenges associated with sampling and studying the heterogeneous and consolidated sulfide deposits typical of hydrothermal vent chimneys.

Here we present rates of microbially-mediated sulfate reduction from three distinct hydrothermal mineral deposits from active hydrothermal 'chimneys' found in the Middle Valley field along the Juan de Fuca Ridge, as well as assessments of bacterial and archaeal diversity, estimates of total biomass and the abundance of functional genes related to sulfate reduction, and in situ geochemistry. These analyses further our understanding of sulfate reduction (including rates, diversity, and distribution of known sulfate-reducing microbes) in vent ecosystems. Moreover, they underscore the potential role of heterotrophic sulfate reduction in hydrothermal systems and constrain its potential influence on both sulfur and carbon cycling.

\section{Materials and methods}

\section{Geologic setting and sampling of hydrothermal deposits}

Middle Valley $\left(48^{\circ} 27^{\prime} \mathrm{N}, 128^{\circ} 59^{\prime} \mathrm{W}\right)$ is an intermediate spreading, axial rift valley located along the Endeavour Segment of the Juan de Fuca Ridge in the Northwest Pacific ocean. Layers of continentallyderived sediments cover Middle Valley, although active hydrothermal vents remain prominent above the sediments. Hydrothermal deposits were collected from three active hydrothermal spires during dive 4625 with the HOV Alvin (R/V Atlantis expedition AT15-67, July 2010) and brought to the surface in a sealed, temperature-insulated polyethylene box. Samples were recovered from actively venting sulfide deposits at Needles (48.45778, - 128.709, 2412.212m, $T_{\max }=123^{\circ} \mathrm{C}$ ), Dead Dog $\left(48.45603,-128.71,2405.268 \mathrm{~m}, T_{\max }=261^{\circ} \mathrm{C}\right)$, and Chowder Hill (48.455543, - 128.709, $2398.257 \mathrm{~m}$, $T_{\max }=261{ }^{\circ} \mathrm{C}$ ) vents. Once on board ship, samples were directly transferred to sterile anaerobic seawater and handled/processed using appropriate sterile microbiological techniques. Subsamples were immediately transferred to gastight jars (Freund Container Inc., Lisle, IL, USA), filled with sterile anaerobic seawater containing $2 \mathrm{~mm}$ sodium sulfide at $\mathrm{pH} 6$, and stored at $4{ }^{\circ} \mathrm{C}$. On return to the laboratory, all samples were maintained in anaerobic seawater $(0.2 \mu \mathrm{m}$ filter-sterilized before use) supplemented

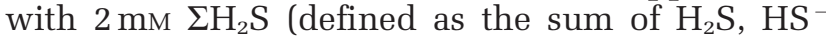
and $\mathrm{S}^{2-}$ ) and adjusted to $\mathrm{pH} 6$. The vent-like media was replenished every 8 to 12 weeks, and all samples were kept in the dark at $4{ }^{\circ} \mathrm{C}$ before incubation.

\section{Vent fluid volatile geochemistry via in situ mass spectrometry}

In situ concentrations of dissolved volatiles (e.g., $\mathrm{H}_{2} \mathrm{~S}, \mathrm{H}_{2}, \mathrm{CO}_{2}, \mathrm{O}_{2}$ and others) were measured at each site with an in situ mass spectrometer as previously described (Wankel et al., 2011). Briefly, dissolved volatiles were quantified in situ by sampling vent effluent for up to $10 \mathrm{~min}$, until partial pressures reached steady state (data were monitored in realtime within the submersible). Concentrations were determined from empirically derived calibrations and validated by comparison with discrete samples collected using titanium gastight samplers.

Measuring sulfate reduction rates (SRRs)

Hydrothermal deposits were homogenized in a commercial blender (Xtreme blender, Waring Inc., Toringtor, CT, USA) under a nitrogen atmosphere. Anaerobic homogenization was designed to minimize fine-scale geochemical and microbial heterogeneity and facilitate more accurate experimental replication. Hydrothermal homogenate (made up of both mineral deposit and interstitial fluid) was aliquoted volumetrically $(7.5 \mathrm{~mL}, c a 29 \mathrm{~g}$ wet weight and $c a 20 \mathrm{~g}$ dry weight) into Balch tubes in an anaerobic chamber. The tubes were supplemented with $15 \mathrm{~mL}$ of sterile artificial vent fluid media designed to mimic the geochemical composition of fluids within the pores of a sulfide deposit $(\mathrm{pH} 6$, $14 \mathrm{~mm} \mathrm{SO}_{4}^{2-}, 2.3 \mathrm{~mm} \mathrm{NaHCO}{ }_{3}, 1 \mathrm{~mm} \mathrm{H}_{2} \mathrm{~S}$, and $10 \mu \mathrm{M}$ each of pyruvate, citrate, formate, acetate, and lactate). Organic acid concentrations are comparable to those measured in situ along the Juan de Fuca Ridge (Lang et al., 2006). Sufficient ${ }^{35} \mathrm{SO}_{4}^{2-}$ was added to achieve $555 \mathrm{kBq}(15 \mu \mathrm{Ci})$ of activity. Owing to technical difficulties with post processing methodology, shipboard incubations using fresh material were not successful. The data 
presented here were generated using samples that had been maintained in sulfidic vent-like effluent (as described above) for 1 year. Samples were incubated anaerobically for 7 days at $4{ }^{\circ} \mathrm{C}, 30^{\circ} \mathrm{C}, 40^{\circ} \mathrm{C}, 50^{\circ} \mathrm{C}$, $60^{\circ} \mathrm{C}, 80^{\circ} \mathrm{C}$, and $90^{\circ} \mathrm{C}$. Controls for sulfate reduction consisted of samples amended with $28 \mathrm{~mm}$ molybdate, a competitive inhibitor of sulfate reduction (Saleh et al., 1964; Newport and Nedwell, 1988). Six biological replicates were run for each treatment, along with three biological replicates for each control. Reactions were quenched with the injection of $5 \mathrm{~mL} 25 \%$ zinc acetate (which is $\sim 20$-fold more zinc than the maximum sulfide concentration), and all samples were frozen at $-20^{\circ} \mathrm{C}$ for further analysis.

To determine SRRs, samples were thawed and the supernatant was removed and filtered through a $0.2 \mu \mathrm{m}$ syringe filter. The crushed deposits that remained in the tube were washed three times with deionized water to remove any remaining sulfate. One gram (wet weight) of crushed deposit was analyzed via chromium distillation (see Supplementary Methods), and SRRs were calculated as in Fossing and Jorgensen (1989) using the following calculation:

$$
S R R=\frac{n S O_{4}^{2-} \cdot a \cdot 1.06}{(a+1+A) \cdot t}
$$

Where $\mathrm{nSO}_{4}^{2-}$ is the quantity (in moles) of sulfate added to each incubation $(14 \mathrm{mM} \times 15 \mathrm{~mL}=210$ $\mu \mathrm{mol}$ ), $a$ is the activity (d.p.m.) of the trapped sulfide, 1.06 is the fractionation factor between the sulfide and sulfate pools, $A$ is the activity of the sulfate pool at the completion of the incubation, and $t$ is the incubation time (days). The rates are presented in units of nmol S g ${ }^{-1}$ day $^{-1}$.

\section{DNA extraction}

Immediately before conducting the rate experiments, a subsample of the homogenized hydrothermal deposit was removed and frozen at $-80^{\circ} \mathrm{C}$ for molecular analysis. This approach ensures that the resulting sequences best represent those communities responsible for the observed activity. DNA was extracted from this crushed deposit sample with a protocol modified from (Santelli et al., 2008). Subsamples were washed with $0.1 \mathrm{~N} \mathrm{HCl}$, followed by two rinses with a sterile solution containing $10 \mathrm{~mm}$ Tris (pH 8.0) and $50 \mathrm{~mm}$ EDTA. A known mass of material was added to PowerSoil beadbeating tubes (MoBio Laboratories, Carlsbad, CA, USA), incubated at $70{ }^{\circ} \mathrm{C}$ for $10 \mathrm{~min}$, and then amended with $200 \mathrm{ng}$ of poly-A. Subsamples were subjected to beadbeating, followed by three freeze-thaw cycles to further lyse cells. Nucleic acids were extracted using hot phenol $\left(60^{\circ} \mathrm{C}\right.$ for $3 \mathrm{~min}$ ), followed by two chloroform:isoamyl alcohol phase extractions and a final precipitation in ethanol. DNA was resuspended in TE ( $\mathrm{pH}$ 8.0) and quantified using the Qubit fluorometer (Life Technologies, Grand Island, NY, USA).
Enumeration of gene abundance via quantitative PCR Quantitative PCR (qPCR) was used to determine the abundance of bacterial and archaeal 16S rRNA genes. To provide additional constraints on the abundance of sulfate-reducing microbes, qPCR was also used to enumerate (A) the adenosine 5 -phosphosulfate reductase (aprA) gene using primers that target both sulfate-reducing bacteria and archaea (Christophersen et al., 2011); (B) bacterial dissimilatory sulfite reductase $(d s r A)$ using primers that target bacteria (Kondo et al., 2004); and (C) Deltaproteobacteria via primers that target their $16 \mathrm{~S}$ rRNA genes (Stults et al., 2001). Quantification was performed in triplicate with the Stratagene MX3005p qPCR System (Agilent Technologies, Santa Clara, CA, USA) using the Perfecta SYBR FastMix with low ROX $(20 \mu \mathrm{l}$ reactions, Quanta Biosciences, Gaitherburg, MD, USA), specific primers and annealing temperatures (Table 1), and $10 \mathrm{ng}$ of template genomic DNA. The thermal cycling conditions for all assays was $94{ }^{\circ} \mathrm{C}$ for $10 \mathrm{~min}, 35$ cycles of $94^{\circ} \mathrm{C}$ for $1 \mathrm{~min}$, the annealing temperature for $1 \mathrm{~min}$ (Table 1), extension at $72{ }^{\circ} \mathrm{C}$ for $30 \mathrm{~s}$, and fluorescence read after $10 \mathrm{~s}$ at $80^{\circ} \mathrm{C}$. Following amplification, dissociation curves were determined across a temperature range of $55-95^{\circ} \mathrm{C}$. Ct values for each well were calculated using the manufacturer's software. Plasmids containing bacterial and archaeal 16S rRNA and functional gene inserts (amplified from Arcobacter nitrofigulis (ATCC 33309), Methanosarcina acidovorans, and Desulfovibrio vulgaris Hildenborough (ATCC 29579/ NCIMB 8303/ AE017285, respectively) were used as standards for calibration (see Supplementary Methods for more detail).

Sequencing and phylogenetic analysis via 454 pyrosequencing

DNA samples were sequenced using 454 pyrotag methods similar to those described previously (Dowd et al., 2008). All samples were sequenced at the Research and Testing Laboratory (Lubbock, TX, USA) using a 454FLX instrument (Roche Inc., Indianapolis, IN, USA) with Titanium reagents. The resulting bacterial and archaeal 16S rRNA (bacterial V1-V3 and archaeal V3-V4 of the 16S rRNA genes; primers are shown in Table 1), as well as $d r s B$ sequences, were analyzed via Mothur (Schloss et al., 2009). Sequences were trimmed, quality checked, aligned to the SILVA-compatible alignment database reference alignment ( $d s r B$ gene data sets were aligned to a $d s r B$ gene database generated from the Ribosomal Database Project (RDP)), analyzed for chimeras, classified against the Greengenes99 database, and clustered into operational taxonomic units (OTUs; see Supplementary Methods for more detail). Rarefaction curves were used to examine the number of OTUs as a function of sampling depth. Alpha diversity was assessed by generating values from the Chao1 richness estimator and the inverse Simpson diversity index. 
Table 1 Primers used for the enumeration of 16S rRNA and sulfate reduction functional genes

\begin{tabular}{|c|c|c|c|c|c|c|c|}
\hline Target gene & Forward primer & Conc (nм) & $\begin{array}{c}T \\
\left({ }^{\circ} C\right)^{\mathrm{a}}\end{array}$ & Reverse primer & $\begin{array}{c}\text { Conc } \\
\text { (nм) }\end{array}$ & $\begin{array}{c}T \\
\left({ }^{\circ} \mathrm{C}\right)^{\mathrm{a}}\end{array}$ & Reference \\
\hline Bacterial 16S & $\begin{array}{l}\text { Bact1369F- 5'-CGGTGA } \\
\text { ATACGTTCYCGG-3' }\end{array}$ & 1000 & 59 & $\begin{array}{l}\text { Prok1541R- 5'-AAGGAGGT } \\
\text { GATCC RGCCGCA-3' }\end{array}$ & 1000 & 59 & Suzuki et al. (2001) \\
\hline Bacterial $16 S^{b}$ & $\begin{array}{l}\text { Gray28F -5'-GAGTTT } \\
\text { GATCNTGGCTCAG-3' }\end{array}$ & 500 & 54 & $\begin{array}{l}\text { Gray519R- 5'- } \\
\text { GTNTTACNGCGGCKGCTG-3' }\end{array}$ & 500 & 54 & $\begin{array}{l}\text { Modified from Frias- } \\
\text { lopez et al. (2002); } \\
\text { modified from } \\
\text { Manefield et al. (2002) }\end{array}$ \\
\hline Archaeal 16S & $\begin{array}{l}\text { Arch1-1369F- 5'-CGGTGA } \\
\text { ATACGTCCCTGC-3' Arch2- } \\
\text { 1369F-5'-CGGTGAA } \\
\text { TATGCCCCTGC-3' }\end{array}$ & 500 (1:1 Mix) & 59 & $\begin{array}{l}\text { Prok1541R- 5'-AAGGAGGT } \\
\text { GATCC RGCCGCA-3' }\end{array}$ & 1000 & 59 & Suzuki et al. (2001) \\
\hline Archaeal $16 S^{b}$ & $\begin{array}{l}\text { Arch349F- 5'-GYGCAS } \\
\text { CAGKCGMGAAW-3' }\end{array}$ & 500 & 54 & $\begin{array}{l}\text { Arch806R- 5'- } \\
\text { GGACTACVSGGGTATCTAAT }\end{array}$ & 500 & 54 & $\begin{array}{l}\text { Takai and Horikoshi } \\
(2000)\end{array}$ \\
\hline$\delta$-Proteobacteria ${ }^{\mathrm{c}}$ & $\begin{array}{l}\text { Delta361GF- 5'-AAGCCT- } \\
\text { GACG } \\
\text { CASCAA-3' }\end{array}$ & 600 & 55 & $\begin{array}{l}\text { Delta685R- ATCTACGGATTT } \\
\text { CACTCCTACA-3' }\end{array}$ & 600 & 55 & Stults et al. (2001) \\
\hline $\begin{array}{l}\text { Disimmilatory } \\
\text { sulfite reductase }\end{array}$ & $\begin{array}{l}\text { DSR1-F + - -5'-ATCGGN } \\
\text { CARGCNTTYCCNTT-3' }\end{array}$ & 400 & 58 & $\begin{array}{l}\text { DSR-R- 5'- } \\
\text { GTGGMRCCGTGCAKRTTGG- } \\
3^{\prime}\end{array}$ & 600 & 58 & Kondo et al. (2004) \\
\hline $\begin{array}{l}\text { Disimmilatory } \\
\text { sulfite reductase }^{\mathrm{e}}\end{array}$ & $\begin{array}{l}\text { DSR2060F 5'-CAACATCG- } \\
\text { TYC } \\
\text { ATACMCAGGG-3' }\end{array}$ & 500 & 50 & $\begin{array}{l}\text { DSR4R- 5'-GTGTAGCAGT- } \\
\text { TACCGCA-3' }\end{array}$ & 500 & 50 & $\begin{array}{l}\text { Wagner et al. (1998); } \\
\text { Oakley et al. (2011) }\end{array}$ \\
\hline $\begin{array}{l}\text { Adenosine } \\
5^{\prime} \text {-phosphosulfate } \\
\text { reductase }\end{array}$ & $\begin{array}{l}\text { aps3F } 5^{\prime} \text {-TGGCAGATCATG } \\
\text { WTYAAYGG-3' }\end{array}$ & 400 & 55 & $\begin{array}{l}\text { aps2R- 5'-GCGCCGTAACCRT } \\
\text { CYTTRAA-3' }^{\prime}\end{array}$ & 400 & 55 & $\begin{array}{l}\text { Christophersen et al. } \\
\text { (2011) }\end{array}$ \\
\hline
\end{tabular}

${ }^{\mathrm{a} A n n e a l i n g ~ t e m p e r a t u r e . ~}$

bPrimers used for 454-pytrotag sequencing, all other primers used for qPCR.

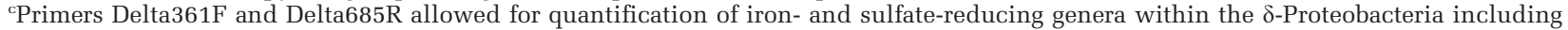
Geobacter, Pelobacter (including fermentative species), Desulfovibrio, Desulfomicrobium, Desulfuromusa, and Desulfuromonas (including dissimilatory S reducers) (Stults et al., 2001).

${ }^{\mathrm{d}}$ Although these primers amplify bacterial $d s r A$ gene sequences, they may not detect some gram-positive species and cannot detect select thermophilic bacterial and archaeal sulfate-reducing lineages (Kondo et al., 2004).

eTargets both bacterial and archaeal aprA gene (Christophersen et al., 2011).

\section{Sequence accession numbers}

The 16S rRNA and $d s r B$ gene sequences reported in this study have been submitted to the Sequence Read Archive under the accession numbers SRX154520 through SRX154528.

\section{Results}

Physical and geochemical characteristics of the study sites

The hydrothermal deposits sampled from Middle Valley were all relatively friable and were composed predominantly of anhydrite $\left(\mathrm{CaSO}_{4}\right.$, $\mathrm{M}$ Tivey, personal communication). Chowder Hill and Dead Dog had the highest observed venting fluid temperatures (measured in situ at $261{ }^{\circ} \mathrm{C}$ ), followed by Needles $\left(123^{\circ} \mathrm{C}\right)$. In situ measurements of dissolved hydrogen sulfide $\left(\mathrm{H}_{2} \mathrm{~S}\right)$ revealed significant differences in hydrothermal fluid composition among hydrothermal deposits. Unfortunately the inline $\mathrm{pH}$ probe with the in situ mass spectrometer malfunctioned during the dive. Using previously reported $\mathrm{pH}$ values (Butterfield et al., 1994a, b), Chowder Hill would have the highest in situ measurement of total sulfide (3.9 mM), followed by Dead Dog (2.2 mM) and Needles (0.59 mu) (Table 2). These concentrations are within the same magnitude of previously reported $\mathrm{H}_{2} \mathrm{~S}$ in focused vent fluids at Middle Valley (Butterfield et al., 1994a). Chowder Hill did exhibit the highest in situ concentration of hydrogen (1.86 mM), followed by Dead Dog (1.66 mm) and Needles $(\sim 1.42 \mathrm{~mm})$. These values are also consistent with previous studies (Cruse and Seewald, 2006), as well as gastight samples collected and analyzed shipboard (M Lilley, personal communication).

\section{Sulfate reduction rates}

Sulfate reduction was observed in all samples at temperatures ranging from $4{ }^{\circ} \mathrm{C}$ to $90{ }^{\circ} \mathrm{C}$ (Figure 1). Maximal rates of sulfate reduction were observed between $88^{\circ} \mathrm{C}$ and $90^{\circ} \mathrm{C}\left(2670 \mathrm{nmolg}^{-1}\right.$ day $^{-1}$ at Needles, $1090 \mathrm{nmolg}^{-1}$ day $^{-1}$ at Chowder Hill and $142 \mathrm{nmol} \mathrm{g}^{-1}$ day $^{-1}$ at Dead Dog; Figure 1). Notably, the highest SRRs were observed in Needles samples, which were $\sim 20$-fold higher than those observed at Dead Dog, and $\sim 2$-fold greater than at Chowder Hill. Many of the rates exhibit large deviations because of the high variability among the biological replicates, most likely due to persistent mineralogical and microbiological heterogeneity across incubations, even after homogenization. Sulfate reduction was also observed in molybdate amended experiments, although we suspect that molybdate was scavenged 
by minerals that attenuated the effect of the inhibitor as has been previously observed in metal-rich environments (Bostick et al., 2003; Xu et al., 2006).

\section{Quantification of taxonomic and functional genes}

Microbial density (as estimated by 16S rRNA gene copies $\mathrm{g}^{-1}$ mineral) was greatest at Needles and lowest at Dead Dog. Microbial communities at each site were dominated by archaea (Figure 2a), with Needles showing the highest ratio of archaea to bacteria (227:1 as compared with 14:1 at Dead Dog or 17.5:1 at Chowder Hill). Assuming an average of 4.19 copies of $16 \mathrm{~S}$ rRNA gene per bacterium and 1.71 copies of $16 \mathrm{~S}$ rRNA gene per archaeon genome (Klappenbach et al., 2001; Lee et al., 2009), Needles hosts a microbial community of $4.12 \times 10^{8}$ cells g ${ }^{-1}$ sample, three orders of magnitude higher than

Table 2 In situ $\sum \mathrm{H}_{2} \mathrm{~S}$ measurements compensated for a range of hydrothermally relevant $\mathrm{pH}$

\begin{tabular}{lccc}
\hline$p H$ & $\begin{array}{c}\text { Chowder Hill } \\
H_{2} S(m M)\end{array}$ & $\begin{array}{c}\text { Dead Dog } \mathrm{H}_{2} \mathrm{~S} \\
(\mathrm{~mm})\end{array}$ & $\begin{array}{c}\text { Needles } \mathrm{H}_{2} \mathrm{~S} \\
(\mathrm{~mm})\end{array}$ \\
\hline $\begin{array}{l}\text { Not pH }_{\text {compensated }} \mathrm{a} \\
3.5\end{array}$ & 3.91 & 2.10 & 0.660 \\
4.0 & 3.9 & 2.1 & 0.55 \\
4.5 & 3.9 & 2.1 & 0.55 \\
5.0 & 3.9 & 2.1 & 0.55 \\
5.5 & $3.9 \mathrm{~b}$ & 2.1 & 0.56 \\
6.0 & 4.0 & $2.2^{\mathrm{b}}$ & $0.56^{\mathrm{b}}$ \\
6.5 & 4.2 & 2.3 & 0.59 \\
7.0 & 4.8 & 2.6 & 0.68 \\
7.5 & 6.8 & 3.7 & 0.96 \\
8.0 & 13 & 7.1 & 1.9 \\
8.2 & 33 & 18 & 4.7 \\
\hline
\end{tabular}

Values represent the median values of the 10 highest sampling points.

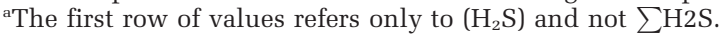

${ }^{\text {b}}$ Total sulfide calculation at the most environmentally relevant $\mathrm{pH}$ (Butterfield et al., 1994).
Chowder Hill $\left(8.96 \times 10^{5}\right.$ cells g $^{-1}$ sample) and Dead Dog $\left(5.65 \times 10^{5}\right.$ cells g $^{-1}$ sample) .

a
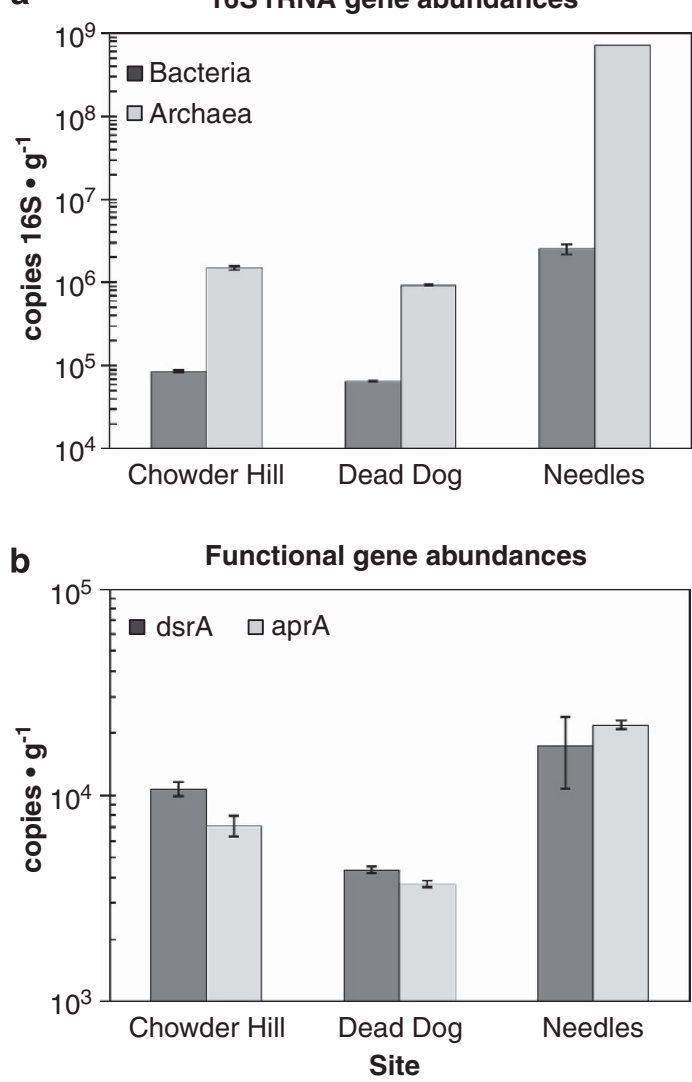

Figure 2 Abundance of (a) 16S rRNA genes and (b) functional gene markers for sulfate reduction across three massive sulfide deposits. Samples of hydrothermal sulfide material were collected from each of the three vent sites, frozen on return to the surface, and DNA was extracted using described protocols. Bacterial and archaeal 16S rRNA, dsrA, and aprA genes were enumerated by qPCR using published primer sets and normalized to grams of extracted sulfide. Error bars represent 1 s.d.
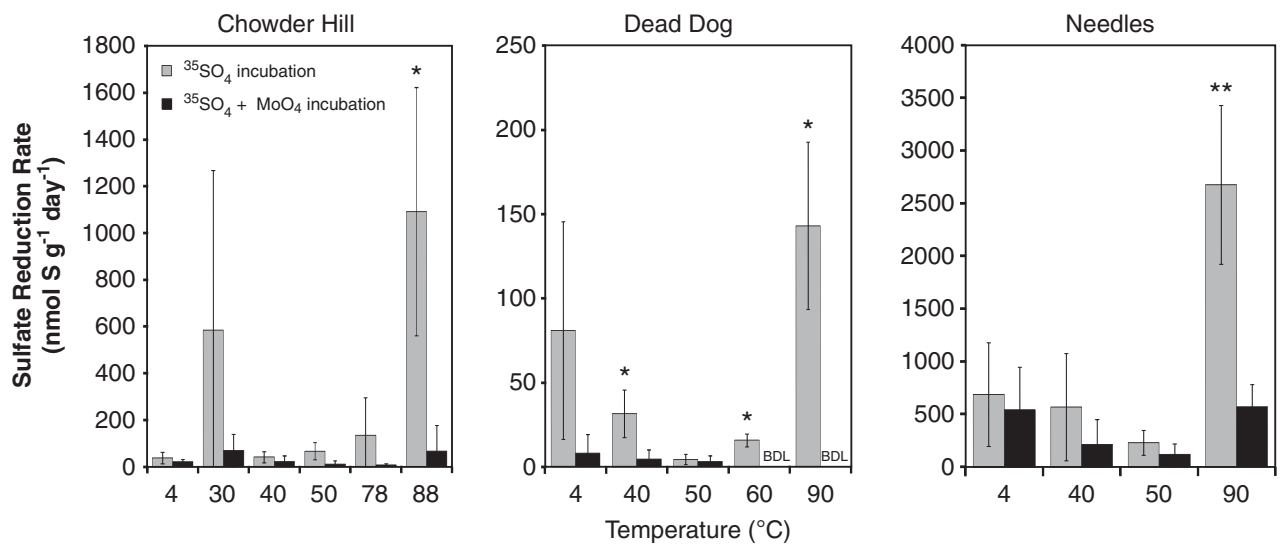

Figure 1 Temperature-dependent sulfate reduction rates in three hydrothermal deposits (Chowder Hill, Dead Dog, and Needles) recovered from Middle Valley. Slurried samples were incubated for 7 days with $(\square)$ or without $(\square)$ the addition of $28 \mathrm{~mm}$ molybdate (a competitive inhibitor for sulfate reduction). Error bars represent 1 s.d. from the average. Statistical significance from the controls (Wilcox-Mann-Whitney) are shown as ${ }^{*} P<0.1,{ }^{*} P<0.05$. Scintillation measurements of 0 c.p.m. for radioactive sulfide (Zn ${ }^{35} \mathrm{~S}$ ) were considered below the detection limit (BDL). 
16S rRNA gene primers specifically targeting ribotypes allied to Desulfovibrio, Desulfomicrobium, Desulfuromusa, and Desulfuromonas were used to enumerate Deltaproteobacteria known to mediate sulfate reduction in many marine systems (Stults et al., 2001). However, given the difficulty in amplifying 16S rRNA genes from deep-sea thermophiles with typical primer sets-because of mismatches with limited sequence representation in GenBank-it is probable that these assays also underestimate abundances in these environments (Teske and Sorensen, 2008). Deltaproteobacterial abundance at Needles was approximately $4.48 \times 10^{5}$ copies $^{-1}$ sample (approximately $26 \%$ of the entire bacterial population), although none were detected at Chowder Hill or Dead Dog (data not shown). The abundance of both functional genes for sulfate reduction, $d s r A$ and $\operatorname{apr} A$, was greatest at Needles and lowest at Dead Dog (a pattern similar to that seen in the 16S rRNA gene abundance estimates; Figure 2b). If we assume an average of one $d s r A$ gene copy per genome (Klein et al., 2001; Kondo et al., 2004), the proportion of sulfatereducing bacteria in the bacterial population is only $2.7 \%$ in Needles as compared with $28 \%$ in Dead Dog and $53 \%$ at Chowder Hill.

\section{Microbial diversity}

454 pyrotag sequencing, rarefaction analyses, and diversity metrics all revealed measureable differences in microbial community composition among the three hydrothermal deposits (Table 3). Via these assessments, Needles hosts the least diverse assemblage of bacteria and archaea, while Chowder Hill and Dead Dog host communities of comparable diversity. Examination of OTUs at $97 \%, 95 \%$, and $92 \%$ sequence similarity further reveal differences in microbial community composition among the three sites. Among archaea at the 97\% level, only two archaeal OTUs $(1 \%$ of all archaeal OTUs classified) are shared among the hydrothermal deposits. The sequences classified to these OTUs represent $69 \%, 48 \%$, and $18 \%$ of all library sequences from Needles, Dead Dog, and Chowder Hill, respectively. One of these OTUs is allied to the ammonium-oxidizing archaeal Candidatus Cenarchaeum in the phylum Thaumarchaeota, and accounts for $35 \%$ of Needles and $<5.0 \%$ of Dead Dog and
Chowder Hill library sequences. The other OTU is allied to a thermophilic sulfur-respiring archaeon within the class Thermoplasmata. Nearly $40 \%$ of the archaeal sequences from Dead Dog were allied to this archaeon. Methanogens allied to Methanocaldococus comprised about $1.0 \%$ of the total archaeal sequences from Dead Dog and were not represented in the libraries from Chowder Hill or Needles. Most of the archaeal diversity at Chowder Hill $(80 \%$ of sequences) and Dead Dog (50\% of sequences) was unclassified. No sequences allied to true sulfatereducing archaeal lineages such as Archaeoglobus fugilis or Aciduliprofundus boonei were recovered. However, the potential diversity of thermophilic sulfate-reducing archaea in these samples is likely much greater than suggested here. This may be explained in part by biases in primer binding, sequencing, or even DNA extractions. For example, the archaeal sequencing primers used in this study only target about $34 \%$ of the Archaeoglobus-like sequences contained in the RDP database (as assayed by Probe Match; Cole et al., 2005). Furthermore, the primers may miss members of the dominant Thermoplasmatales, as in silico analysis only returns $48 \%(1715 / 3558$ sequences) of the RDP reported sequences. Together, these archaeal sequencing primers (349F-806R) miss $42 \%$ of the total archaeal sequences (67 713/117 373 sequences) in the RDP database. Similar bias has been reported in other studies in the deep-sea and deep-subsurface biotopes (for example, Dhillon et al., 2003, 2005, Teske et al., 2008).

Among bacteria at the $97 \%$ similarity level, 54 of the classified bacterial OTUs $(7.0 \%)$ were shared among all hydrothermal deposits and account for $84 \%, 80 \%, 71 \%$ of the sequences from Chowder Hill, Needles, and Dead Dog, respectively (Figure 4). One of these OTUs accounted for $44 \%, 36 \%$, and $25 \%$ of the sequences from Chowder Hill, Dead Dog, and Needles, respectively. Aligning representative sequences from this OTU via Blastn (Altschul et al., 1997) revealed a best match to Thermodesulfovibrio, an anaerobic, thermophilic, sulfate-reducing bacterium from the phylum Nitrospira (81\% identity). Given its abundance, we postulate that it likely contributes substantially to the high thermophilic SRRs. Furthermore, the $d s r B$ gene library was dominated by sequences phylogenetically allied to Thermodesulfovibrio (Supplementary Table S1).

Table 3 16S rRNA sequence tag and alpha diversity characteristics among sites

\begin{tabular}{|c|c|c|c|c|c|c|c|}
\hline Sample & Trimmed reads & Sampled reads & $O T U(97 \%)$ & Coverage & Npshannon & Simpson & Chao \\
\hline Chowder Hill-bacteria & 3997 & 3544 & 340 & 0.948 & 3.30 & 0.168 & 647.23 \\
\hline Dead Dog-bacteria & 3544 & 3544 & 341 & 0.957 & 3.69 & 0.141 & 572.12 \\
\hline Needles-bacteria & 3983 & 3544 & 278 & 0.966 & 3.19 & 0.203 & 458.02 \\
\hline Chowder Hill-archaea & 783 & 308 & 76 & 0.877 & 3.59 & 0.095 & 134.58 \\
\hline Dead Dog-archaea & 308 & 308 & 58 & 0.903 & 3.34 & 0.071 & 97.55 \\
\hline Needles-archaea & 2587 & 308 & 35 & 0.938 & 2.24 & 0.233 & 63.5 \\
\hline
\end{tabular}

Abbreviation: OTU, operational taxonomic unit. 
Other dominant groups of bacteria include members of the Gammaproteobacteria, Bacteroidetes, Deltaproteobacteria, and Alpha proteobacteria. Via Blastn, most of the unclassified sequences matched to partial 16S rRNA gene sequences from hydrothermal vent fluid communities (Nunoura et al., 2010; Sylvan et al., 2012). Sequences classified as Deltaproteobacteria comprised $5.5 \%, 8.2 \%$, and $14 \%$ of the total population of Chowder Hill, Needles, and Dead Dog, respectively. Although the Dead Dog library had the highest proportion of Deltaproteobacteria, sequences related to known sulfate reducers within the Deltaproteobacteria (Desulfobacteraceae, Desulfobulbus rhabdoformis, and Desulfovibrio) were only found at Needles and comprised $1.1 \%$ of the $16 \mathrm{~S}$ rRNA gene library. The majority of the sequences classified as Deltaproteobacteria in each of the three sites were from one unclassified Deltaproteobacterial OTU and comprised of $4.4 \%, 5.3 \%$, and $13 \%$ of the sequences from Chowder Hill, Needles, and Dead Dog, respectively.

\section{Discussion}

SRRs measured in deposits recovered from the Middle Valley vent field reveal the potential for active sulfate reduction within hydrothermal deposits. The magnitude of all measured rates (from $15.7 \mathrm{nmolg}^{-1} \mathrm{day}^{-1}$ at Dead Dog at $60{ }^{\circ} \mathrm{C}$ to $2670 \mathrm{nmolg}^{-1}$ day $^{-1}$ at Needles at $90^{\circ} \mathrm{C}$ ) is comparable in magnitude to those previously observed in hydrothermally influenced sediments (for example, Guaymas basin or Lake Tanganyika; Elsgaard, et al., 1994a, b; Weber and Jorgensen, 2002; Kallmeyer and Boetius, 2004), although the availability of organic carbon is markedly higher in those hydrothermal vent sediments, with Guaymas having up to 200-times greater concentrations of organic carbon (Chen et al., 1993; Cruse and Seewald, 2006; Lang et al., 2006). However, these rates are measurably higher than those typically observed in non hydrothermal deep-sea sediments $\left(0.1-10 \mathrm{nmol} \mathrm{g}^{-1}\right.$ day $^{-1}$, converted here for comparison by assuming an average sediment density of $2 \mathrm{~g} \mathrm{~cm}^{-3}$; Elsgaard, et al., 1994a; Weber and Jorgensen, 2002; Joye et al., 2004). To date, the only other measurement of sulfate reduction from sulfide deposits along the East Pacific Rise exhibited rates comparable to those reported here, (Bonch-Osmolovskaya et al., 2011), but it should be noted that their samples were incubated under a pure $\mathrm{H}_{2}$ atmosphere and likely represented autotrophic sulfate reduction.

Notably, the maximum rates of sulfate reduction in Middle Valley sulfides occurred at $90^{\circ} \mathrm{C}$ in all three deposits. This is in contrast to measurements of sulfate reduction in hydrothermal sediments, where the greatest rates are often observed between $40{ }^{\circ} \mathrm{C}$ and $70^{\circ} \mathrm{C}$, and more modest rates of sulfate reduction have been reported between $80^{\circ} \mathrm{C}$ and $91{ }^{\circ} \mathrm{C}$ (Elsgaard, et al., 1994a, b;; Weber and
Jorgensen, 2002). The relatively low or insignificant SRRs between $4{ }^{\circ} \mathrm{C}$ and $80^{\circ} \mathrm{C}$ suggest that Middle Valley deposits harbor a high proportion of hyperthermophilic sulfate-reducing microbes.

The significant differences in the rates we observed among deposits (Kruskal-Wallis, $P<0.0001$ ) are likely due to differences in biomass and the composition of microbial communities. These differences in density and composition are, in turn, a reflection of the availability of relevant substrates and the physicochemical conditions at each site. Indeed, microbial biomass (as estimated by 16S rRNA genes) directly correlates to rates of activity and is likely one of the strongest factors affecting the observed rates of sulfate reduction (Pearson correlation coefficient $r=0.879$, $P<0.0005)$. Needles had both the highest observed rates as well as the highest cell density (Figures 2 and 3). Of all the deposits sampled, Needles had the lowest venting fluid temperature $\left(123^{\circ} \mathrm{C}\right)$ resulting in the largest zone of microbial habitability. Consistent with this observation, Needles also had the greatest abundance of $d s r A$ and aprA genes per gram, suggesting a larger potential sulfate-reducing community. Here, Deltaproteobacteria allied to Desulfovibrio, Desulfobulbus, Desulfobacteria, and Desulfuromonas accounted for $25.7 \%$ of the bacterial community. These clades of Deltaproteobacteria were not observed at Chowder Hill or Dead Dog by either qPCR or pyrosequencing. Cultured representatives from some of these Deltaproteobacterial clades (Desulfovibrio vulgaris and Desulfovibrio desulfuricans) have been shown to reduce sulfate at high rates (ranging from 10 to $1340 \mathrm{nmolmin}^{-1} \mathrm{mg}^{-1}$ protein) with varying electron donors (Cypionka and Konstanz, 1989; Fitz and Cypionka, 1991).

Thermodesulfovibrio-like organisms dominated the bacterial communities within each hydrothermal deposit (35-44\%; Figure 4). Thermodesulfovibrio sp. are considered obligately anaerobic, thermophilic bacteria that can reduce sulfate and other sulfur compounds (Garrity and Holt, 2001). In pure cultures, members of this genus are able to link growth with hydrogen and a limited range of organic carbon molecules (formate, pyruvate, and lactate), maintaining optimal growth between $55^{\circ} \mathrm{C}$ and $70{ }^{\circ} \mathrm{C}$ (Sekiguchi et al., 2008). Needles had a greater proportion of sequences (from pyrosequencing) related to Thermodesulfovibrio-like species than the other two deposits. The combination of sequences related to a thermophilic sulfate-reducing bacteria and higher rates of sulfate reduction at elevated temperatures $\left(90^{\circ} \mathrm{C}\right)$ suggests that Thermodesulfovibrio-like organisms may have a substantial role in sulfate reduction in warmer environments. However, constraining the relative proportion of sulfate reduction by Thermodesulfovibrio-like organisms in these mixed communities was beyond the scope of this study.

It is unclear why Chowder Hill and Dead Dog exhibited large differences in rates of sulfate reduction despite other similarities in geochemistry and 
biomass. One plausible explanation might be that different types of biological interactions (e.g., syntrophy or competition) occur because of differences in the composition and distribution of microbial communities within the mineral matrix of each deposit. Slight differences in community composition, such as Dead Dog having a higher representation of sequences related to sulfurrespiring (Thermoplasmata) and methanogenic (Methanocaldococus-like) archaea than Chowder

a

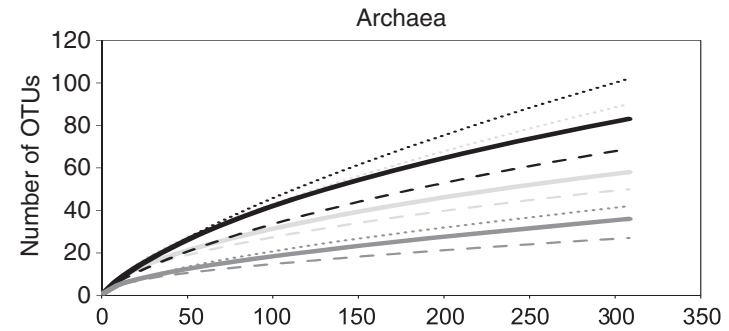

b

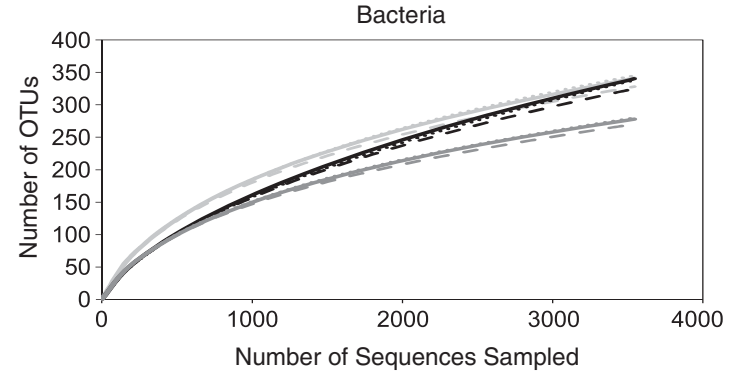

...... Chowder Hill (unique) ….. Dead Dog (unique) ..... Needles (unique) $\begin{array}{lll}- \text { Chowder Hill }(97 \%) & \text { Dead Dog }(97 \%) & \text { Needles }(97 \%) \\ - \text { Chowder Hill }(95 \%) & - \text { Dead Dog }(95 \%) & - \text { Needles }(95 \%)\end{array}$

Figure 3 Rarefaction analysis of archaeal (a) and bacterial (b) sequences from each site at OTU clustering at the 95\%, 97\% and unique level. All 16S rRNA libraries were randomly sampled down to the smallest sample size, (a) $n=308$ (Dead Dog), (b) $n=3544$ (Dead Dog). For both bacteria and archaea, Needles had the least diverse populations.
Hill, may reflect differences in biological interactions, which have implications for rates of sulfate reduction in each deposit. Also, substrate competition for $\mathrm{H}_{2}$ or consumption of locally produced DOC (Oremland and Polcin, 1982; Lovley and Phillips, 1987) may be more prevalent in one deposit over another. Future experiments should aim to better resolve how specific interactions between populations, for example, syntrophy or competition for a common substrate, may influence sulfate reduction.

The potential role of heterotrophic sulfate reduction in productivity and biogeochemistry

Heterotrophic sulfate reduction is likely a prominent metabolic mode within Middle Valley sulfides and sediments, and the SRR data herein (which solely measure hetrotrophic sulfate reduction) support that supposition. Sedimented vent fields typically contain allochthonous organic carbon that could readily support heterotrophy. Indeed, at Middle Valley, bottom waters contain $3.5 \mathrm{mg}$ $\mathrm{DOC} \cdot \mathrm{L}^{-1}$ (about seven-fold higher than the overlying surface seawater), whereas porewater concentrations range from 0.1 to $84.0 \mathrm{mg} \mathrm{DOC} \cdot \mathrm{L}^{-1}$ at sediment depths to 200 mbsf (Ran and Simoneit, 1994). Based on data from culture studies of Desulfovibrio strains, including the $\mathrm{H}^{+} / \mathrm{H}_{2}$ ratio of 1.0 for Desulfovibrio vulgarius Marburg (Fitz and Cypionka, 1991), a $\mathrm{P} / 2 \mathrm{e}^{-}$ratio of $1 / 3$ for Desulfovibrio gigas (this is the number of ATPs produced for every two electrons transferred to an electron acceptor (Barton et al., 2003), and the assumption that $10 \%$ of ATP production supports growth $(20 \mathrm{mmol}$ ATP per gram biomass), our estimates suggest that-at our maximum empirically measured rates-heterotrophic sulfate reduction could support $140 \mathrm{~g}$ biomass $\mathrm{yr}^{-1}$ $\left(\sim 1.5 \times 10^{14}\right.$ cells) at Chowder Hill (volume $=109$ $\left.900 \mathrm{~cm}^{3}\right), 16 \mathrm{~g}$ biomass $\mathrm{yr}^{-1}\left(\sim 1.7 \times 10^{13}\right.$ cells $)$ at
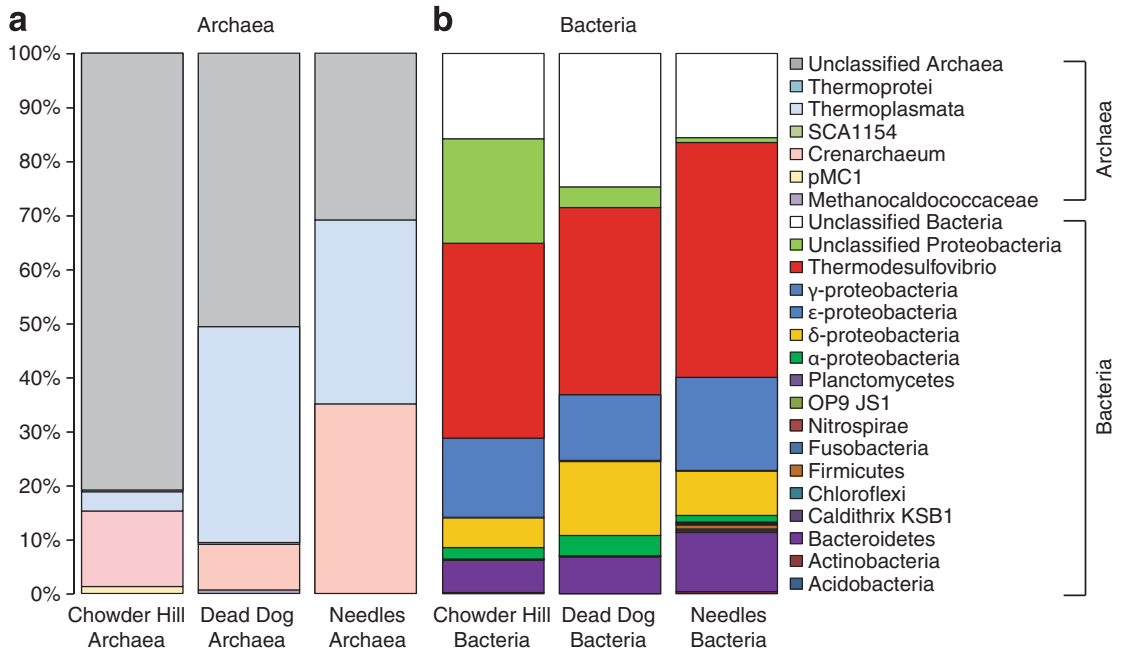

Figure 4 Archaeal (a) and Bacterial (b) taxonomic distribution among the different hydrothermal deposits revealed differences in microbial community composition. Bacterial V1-V3 region and archaeal V3-V4 regions of the 16S were sequenced by 454, analyzed with Mothur, and all libraries were randomly sampled down to the smallest sample size, (a) $n=308$ (Dead Dog), (b) $n=3544$ (Dead Dog). 
Needles (volume $=5495 \mathrm{~cm}^{3}$ ), and $2.1 \mathrm{~g}$ biomass $\mathrm{yr}^{-1}\left(\sim 2.2 \times 10^{12}\right.$ cells) at Dead Dog (volume $=12$ $560 \mathrm{~cm}^{3}$ ). These values are modest in comparison to global estimates of chemoautotrophic biomass production on the global ridge system $\left(10^{10}-10^{13} \mathrm{~g}\right.$ of biomass $\mathrm{yr}^{-1}$; McCollom and Shock, 1997; Bach and Edwards, 2003), yet may be significant in the context of local secondary productivity. Moreover, with respect to the sulfur cycle, the sulfide produced by these heterotrophic sulfate reducers could represent up to $3 \%$ of the $\mathrm{H}_{2} \mathrm{~S}$ flux from Middle Valley deposits (given previously published vent fluid flow rates from the Main Endeavor field; Wankel et al., 2011), which can influence, for example, sulfur isotope biogeochemistry. Additional rate measurements that represent the diversity of physicochemical conditions found within deposits or ridge systems are necessary to better constrain the contribution of heterotrophic sulfate reducers to global vent biomass and geochemistry.

Hydrothermal vents are dynamic environments where carbon and sulfur cycling are intimately linked. Both autotrophic and heterotrophic sulfatereducing microbes have been isolated from vents, and the data shown here are among the first to constrain the potential for heterotorophic sulfate reduction at vents (in particular those with higher organic carbon loads), as well as the relationship between SRRs, temperature, microbial biomass, and community density and composition. These data, as well as the vent field estimates of sulfate reduction, underscore the relevance of sulfate reduction in hydrothermal ecosystems and further indicate the need for continued studies of sulfur cycling along ridge systems.

\section{Acknowledgements}

We are grateful for the expert assistance of the $R / V$ Atlantis crews and the pilots and team of the DSV Alvin for enabling the collections of hydrothermal deposits used in our experiments. We also thank Steve Sansone, Dr Joseph Ring, Ms Julie Hanlon, Dr Kathleen Scott, Dr Vladimir Samarkin, Dr David Johnston and Dr Jan Amend for providing assistance with various technical aspects of the experiments. We are also very thankful for the constructive feedback from the reviewers. Financial support for this research was provided by the National Science Foundation (NSF OCE-0838107 and NSF OCE-1061934 to PR Girguis), and the National Aeronautic and Space Administration (NASA-ASTEP NNX09AB78G to C Scholin and PR Girguis and NASA-ASTEP NNX07AV51G to A Knoll and PR Girguis).

\section{References}

Alazard D, Dukan S, Urios A, Verhe F, Bouabida N, Morel F et al. (2003). Desulfovibrio hydrothermalis sp nov., a novel sulfate-reducing bacterium isolated from hydrothermal vents. Int $J$ Syst Evol Microbiol 53: 173-178.
Altschul SF, Madden TL, Schäffer AA, Zhang J, Zhang Z, Miller W et al. (1997). Gapped BLAST and PSI-BLAST: a new generation of protein database search programs. Nucleic Acids Res 25: 3389-3402.

Amend JP, Shock EL. (2001). Energetics of overall metabolic reactions of thermophilic and hyperthermophilic archaea and bacteria. Fems Microbiology Reviews 25: 175-243.

Audiffrin C, Cayol JL, Joulian C, Casalot L, Thomas P, Garcia JL et al. (2003). Desulfonauticus submarinus gen. nov., sp nov., a novel sulfate-reducing bacterium isolated from a deep-sea hydrothermal vent. Int J Syst Evol Microbiol 53: 1585-1590.

Bach W, Edwards KJ. (2003). Iron and sulfide oxidation within the basaltic ocean crust: implications for chemolithoautotrophic microbial biomass production. Geochimica et Cosmochimica 67: 3871-3887.

Barton LL, Hamilton WA, Thauer RK, Stackebrandt E, Legall J, Odom JM et al. (2003). Energy metabolism and phylogenetic diversity of sulphate-reducing bacteria. In Hamilton WA, Barton LL (eds) SulphateReducting Bacteria: Environmental and Engineered Systems. Cambridge University Press, pp 1-10.

Blöchl E, Rachel R, Burggraf S, Hafenbradl D, Jannasch HW, Stetter KO. (1997). Pyrolobus fumarii, gen. and sp. nov., represents a novel group of archaea, extending the upper temperature limit for life to 113 degrees C. Extremophiles 1: 14-21.

Bonch-Osmolovskaya E, Perevalova A, Kolganova TV, Rusanov II, Jeanthon C, Pimenov NV. (2011). Activity and distribution of thermophilic prokaryotes in hydrothermal fluid, sulfidic structures, and sheaths of alvinellids (East Pacific Rise, $13^{\circ} \mathrm{N}$ ). Appl Environ Microbiol 77: 2803-2806.

Bostick BC, Fendorf S, Helz GR. (2003). Differential adsorption of molybdate and tetrathiomolybdate on pyrite (FeS2). Environ Sci Technol 37: 285-291.

Butterfield DA, Mcduff RE, Franklin J, Wheat CG. (1994a). Geochemistry of hydrothermal vent fluids from Middle Valley, Juan de Fuca ridge. Proc ODP Sci Res 139: 395-410.

Butterfield DA, McDuff RE, Mottl MJ, Lilley MD, Lupton JE, Massoth GJ. (1994b). Gradients in the composition of hydrothermal fluids from the endeavour segment vent field: phase separation and brine loss. J Geophys Res 99: 9561-9583.

Campbell BJ, Engel AS, Porter ML, Takai K. (2006). The versatile epsilon-proteobacteria: key players in sulphidic habitats. Nat Rev Microbiol 4: 458-468.

Canfield DE. (1989). Sulfate Reduction and oxic respiration in marine- sediments- Implications for organiccarbon preservation in euxinic envrionments. Deep Sea Res Pt A Oceanographic Res Papers 36: 121-138.

Chen RF, Bada JL, Suzuk Y. (1993). The relationship between dissolved organic carbon ( DOC ) and fluorescence in anoxic marine porewaters: implications for estimating benthic DOC fluxes. Geochimica Et Cosmochimica Acta 57: 2149-2153.

Christophersen CT, Morrison M, Conlon MA. (2011). Overestimation of the abundance of sulfate-reducing bacteria in human feces by quantitative PCR targeting the Desulfovibrio 16S rRNA gene. Appl Environ Microbiol 77: 3544-3546.

Cole JR, Chai B, Farris RJ, Wang Q, Kulam S, McGarrell $\mathrm{DM}$ et al. (2005). The Ribosomal Database Project (RDP-II): sequences and tools for high-throughput rRNA analysis. Nucleic Acids Res 33: D294-D296. 
Cruse AM, Seewald JS. (2006). Geochemistry of lowmolecular weight hydrocarbons in hydrothermal fluids from Middle Valley, northern Juan de Fuca Ridge. Geochimica Et Cosmochimica Acta 70: 2073-2092.

Cypionka H, Konstanz U. (1989). Characterization of sulfate transport in Desulfovibrio desulfuricans. Arch Microbiol 152: 237-243.

Dittmar W. (1884). Report on researches into the composition of ocean water, collected by the HMS Challenger, during the years 1873-1876. Rept Sci Results Voyage HMS Challenger (Phys Chem) 1: 1-251.

Dhillon A, Lever M, Lloyd KG, Albert DB, Sogin ML, Teske A. (2005). Methanogen diversity evidenced by molecular characterization of methyl coenzyme $M$ reductase A (mcrA) genes in hydrothermal sediments of the Guaymas Basin. Appl Environ Microbiol 71: 4592-4601.

Dhillon A, Teske A, Dillon J, Stahl DA, Sogin ML. (2003). Molecular characterization of sulfate-reducing bacteria in the Guaymas Basin. Appl Environ Microbiol 69: $2765-2772$.

Dowd SE, Sun Y, Secor PR, Rhoads DD, Wolcott BM, James GA et al. (2008). Survey of bacterial diversity in chronic wounds using Pyrosequencing, DGGE, and full ribosome shotgun sequencing. BMC Microbiol 8: 43.

Elsgaard L, Guezennec J, Benbouzidrollet N, Prieur D. (1995). Mesophilic sulfate-reducing bacteria from 3 deep-sea hydrothermal vent sites. Oceanologica Acta 18: 95-104.

Elsgaard L, Isaksen MF, Jorgensen BB, Alayse AM, Jannasch HW. (1994a). Microbial sulfate reduction in deep-sea sediments at the Guaymas Basin hydrothermal vent area: influence of temperature and substrates. Geochimica Et Cosmochimica Acta 58: 3335-3343.

Elsgaard L, Prieur D, Mukwaya GM, Jorgensen BB. (1994b). Thermophilic sulfate reduction in hydrothermal sediment of lake tanganyika, East Africa. Appl Environ Microbiol 60: 1473-1480.

Fitz R, Cypionka H. (1991). Generation of a proton gradient in Desulfovibrio vulgaris. Arch Microbiol 155: $444-448$.

Fossing H, Jorgensen BB. (1989). Chromium reduction method of bacterial sulfate reduction in sediments: measurement reduction of a single-step chromium method evaluation. Biogeochemistry 8: 205-222.

Frias-lopez J, Zerkle AL, Bonheyo GT, Fouke BW. (2002). Partitioning of bacterial communities between seawater and healthy, black band diseased, and dead coral surfaces. Appl Environ Microbiol 68: 2214-2228.

Garrity GM, Holt JG. (2001). The road map to the manual. In Castenholz RW,, Garrity GM (eds) Bergys Manual of Systematic Bacteriology. Springer: New York, NY, USA, pp 119-166.

Hoek J, Banta A, Hubler F, Reysenbach AL. (2003). Microbial diversity of a sulphide spire located in the Edmond deep-sea hydrothermal vent field on the Central Indian Ridge. Geobiology 1: 119-127.

Houghton JL, Seyfried WE, Banta AB, Reysenbach AL. (2007). Continuous enrichment culturing of thermophiles under sulfate and nitrate-reducing conditions and at deep-sea hydrostatic pressures. Extremophiles 11: 371-382.

Huber JA, Welch DM, Morrison HG, Huse SM, Neal PR, Butterfield DA et al. (2007). Microbial population structures in the deep marine biosphere. Science 318: 97-100.

Jannasch HW, Mottl MJ. (1985). Geomicrobiology of deepsea hydrothermal vents. Science 229: 717-725.

Jannasch HW, Wirsen CO, Molyneaux SJ, Langworthy TA. (1988). Extremely thermophilic fermentative archaebacteria of the genus Desulfurococcus from deep-sea hydrothermal vents. Appl Environ Microbiol 54: 1203-1209.

Johnson KS, Beehler CL, Sakamoto-Arnold C, Childress J. (1986). In situ measurements of chemical distributions in a deep-sea hydrothermal vent field. Science 231: 1139-1141.

Jorgensen BB, Isaksen MF, Jannasch HW. (1992). Bacterial sulfate reduction above 100-degrees-C in deep-sea hydrothermal vent sediments. Science 258: 1756-1757.

Joye SB, Boetius A, Orcutt BN, Montoya JP, Schulz HN, Erickson MJ et al. (2004). The anaerobic oxidation of methane and sulfate reduction in sediments from Gulf of Mexico cold seeps. Chem Geol 205: 219-238.

Kallmeyer J, Boetius A. (2004). Effects of temperature and pressure on sulfate reduction and anaerobic oxidation of methane in hydrothermal sediments of Guaymas basin. Appl Environ Microbiol 70: 1231-1233.

Klappenbach J, Saxman PR, Cole JR, Schmidt TM. (2001). Rrndb: the ribosomal RNA operon copy number database. Nucleic Acids Res 29: 181-184.

Klein M, Friedrich M, Roger AJ, Hugenholtz P, Fishbain S, Abicht $\mathrm{H}$ et al. (2001). Multiple lateral transfers of dissimilatory sulfite reductase genes between major lineages of sulfate-reducing prokaryotes. Appl Environ Microbiol 183: 6028-6035.

Kondo R, Nedwell DB, Purdy KJ, Silva SQ. (2004). Detection and enumeration of sulphate-reducing bacteria in estuarine sediments by competitive PCR. Geomicrobiol J 21: 145-157.

Lang SQ, Butterfield DA, Lilley MD, Johnson HP, Hedges JI. (2006). Dissolved organic carbon in ridge-axis and ridge-flank hydrothermal systems. Geochimica et Cosmochimica Acta 70: 3830-3842.

Lee ZM-P, Bussema C, Schmidt TM. (2009). rrnDB: documenting the number of rRNA and tRNA genes in bacteria and archaea. Nucleic Acids Res 37: 489-493.

Lovley DR, Phillips EJ. (1987). Competitive mechanisms for inhibition of sulfate reduction and methane production in the zone of ferric iron reduction in sediments. Appl Environ Microbiol 53: 2636-2641.

Manefield M, Whiteley AS, Griffiths RI, Bailey MJ. (2002). RNA stable isotope probing, a novel means of linking microbial community function to phylogeny. Appl Environ Microbiol 68: 5367-5373.

McCollom TM, Shock EL. (1997). Geochemical constraints on chemolithoautotrophic metabolism by microorganisms in seafloor hydrothermal systems. Geochimica et Cosmochimica Acta 61: 4375-4391.

Muyzer G, Stams AJM. (2008). The ecology and biotechnology of sulphate-reducing bacteria. Nat Rev Microbiol 6: 441-544.

Nakagawa S, Takai K, Inagaki F, Hirayama H, Nunoura T, Horikoshi K et al. (2005). Distribution, phylogenetic diversity and physiological characteristics of epsilonProteobacteria in a deep-sea hydrothermal field. Environ Microbiol 7: 1619-1632.

Nakagawa S, Takai K. (2008). Deep-sea vent chemoautotrophs: diversity, biochemistry and ecological significance. FEMS Microbiol Ecol 65: 1-14. 
Nakagawa T, Nakagawa S, Inagaki F, Takai K, Horikoshi K. (2004). Phylogenetic diversity of sulfate-reducing prokaryotes in active deep-sea hydrothermal vent chimney structures. FEMS Microbiol Let 232: 145-152.

Nercessian O, Bienvenu N, Moreira D, Prieur D, Jeanthon C. (2005). Diversity of functional genes of methanogens, methanotrophs and sulfate reducers in deep-sea hydrothermal environments. Environ Microbiol 7: 118-132.

Newport PJ, Nedwell DB. (1988). The mechanisms of inhibition of Desulfovibrio and Desulfotomaculum species by selenate and molybdate. J Appl Microbiol 65: 419-423.

Nunoura T, Oida H, Nakaseama M, Kosaka A, Ohkubo SB, Kikuchi $\mathrm{T}$ et al. (2010). Archaeal diversity and distribution along thermal and geochemical gradients in hydrothermal sediments at the Yonaguni Knoll IV hydrothermal field in the Southern Okinawa trough. Appl Environ Microbiol 76: 1198-1211.

Oakley BB, Carbonero F, Dowd Scot E, Hawkins RJ, Purdy KJ. (2011). Contrasting patterns of niche partitioning between two anaerobic terminal oxidizers of organic matter. ISME J 6: 905-914.

Oremland RS, Polcin S. (1982). Methanogenesis and sulfate reduction: competitive and noncompetitive substrates in estuarine sediments. Appl Environ Microbiol 44: 1270-1276.

Ran B, Simoneit BRT. (1994). Dissolved organic carbon in interstitial waters from sediments of Middle Valley, Leg 139 1. Proc ODP Sci Res 139: 441-446.

Saleh AM, Macpherson R, Miller JDA. (1964). The effect of inhibitors on sulphate reducing bacteria: a compilation. J Appl Microbiol 27: 281-293.

Santelli CM, Orcutt BN, Banning E, Bach W, Moyer CL, Sogin ML et al. (2008). Abundance and diversity of microbial life in ocean crust. Nature 453: 653-657.

Schloss PD, Westcott SL, Ryabin T, Hall JRA, Hartmann M, Hollister EB et al. (2009). Introducing mothur: opensource, platform-independent, community-supported software for describing and comparing microbial communities. Appl Environ Microbiol 75: 7537-7541.

Schrenk MO, Kelley DS, Delaney JR, Baross JA. (2003). Incidence and diversity of microorganisms within the walls of an active deep-sea sulfide chimney. Appl Environ Microbiol 69: 3580-3592.

Sekiguchi Y, Muramatsu M, Imachi H, Narihiro T, Ohashi A, Harada $\mathrm{H}$ et al. (2008). Thermodesulfovibrio aggregans sp. nov. and Thermodesulfovibrio thiophilus sp. nov., anaerobic, thermophilic, sulfate-reducing bacteria isolated from thermophilic methanogenic sludge, and emended description of the genus Thermodesulfovibrio. Int J Syst Evol Microbiol 58: 2541-2548.

Stults JR, Snoeyenbos-West O, Methe B, Lovley DR, Chandler DP. (2001). Application of the $5^{\prime}$ fluorogenic exonuclease assay (TaqMan) for quantitative ribosomal DNA and rRNA analysis in sediments. Appl Environ Microbiol 67: 2781-2789.

Suzuki MT, Beja O, Taylor LT, DeLong EF. (2001). Phylogenetic analysis of ribosomal RNA operons from uncultivated coastal marine bacterioplankton. Environ Microbiol 3: 323-331.

Sylvan JB, Toner BM, Edwards KJ. (2012). Life and death of deep-sea vents: bacterial diversity and ecosystem succession on inactive hydrothermal sulfides. mBio 3 : e00279-11.

Takai K, Horikoshi K. (2000). Rapid detection and quantification of members of the archaeal community by quantitative PCR using fluorogenic probes. Appl Environ Microbiol 66: 5066-5072.

Teske A, Sorensen KB. (2008). Uncultured archaea in deep marine subsurface sediments: have we caught them all? ISME J 2: 3-18.

Wagner M, Roger AJ, Flax JL, Brusseau GA, Stahl DA. (1998). Phylogeny of dissimilatory sulfite reductases supports an early origin of sulfate respiration. J Bact 180: $2975-2982$.

Wankel SD, Germanovich LN, Lilley Marvin D, Genc G, DiPerna CJ, Bradley AS et al. (2011). Influence of subsurface biosphere on geochemical fluxes from diffuse hydrothermal fluids. Nat Geo 4: 461-468.

Weber A, Jorgensen BB. (2002). Bacterial sulfate reduction in hydrothermal sediments of the Guaymas Basin, Gulf of California, Mexico. Deep-Sea Res Pt I-Oceanographic Res Papers 49: 827-841.

Xu N, Christodoulatos C, Braida W. (2006). Adsorption of molybdate and tetrathiomolybdate onto pyrite and goethite: effect of $\mathrm{pH}$ and competitive anions. Chemosphere 62: 1726-1735.

(1) $\Theta \Theta$ This work is licensed under the Creative Commons Attribution-NonCommercialNo Derivs Works 3.0 Unported License. To view a copy of this license, visit http://creativecommons.org/ licenses/by-nc-nd/3.0/

Supplementary Information accompanies this paper on The ISME Journal website (http://www.nature.com/ismej) 